\title{
Correction to: Topical Low Dose Preservative-Free Hydrocortisone Reduces Signs and Symptoms in Patients with Chronic Dry Eye: A Randomized Clinical Trial
}

\author{
Martin Kallab - Stephan Szegedi - Nikolaus Hommer - Hannes Stegmann • \\ Semira Kaya · René M. Werkmeister • Doreen Schmidl • \\ Leopold Schmetterer $\cdot$ Gerhard Garhöfer
}

Published online: December 10, 2019

(C) The Author(s) 2019

Correction to: Adv Ther

https://doi.org/10.1007/s12325-019-01137-8

The article "Topical Low Dose Preservative-Free Hydrocortisone Reduces Signs and Symptoms in Patients with Chronic Dry Eye: A Randomized Clinical Trial", written by Martin Kallab, Stephan Szegedi, Nikolaus Hommer, Hannes Stegmann, Semira Kaya, René M. Werkmeister, Doreen Schmidl, Leopold Schmetterer, Gerhard Garhöfer was originally published electronically on the publisher's internet portal (currently SpringerLink) on November 19, 2019 without open access.

The copyright of the article changed to $($ C The Author(s) 2019 and the article is forthwith

The original article can be found online at https://doi. org/10.1007/s12325-019-01137-8.

M. Kallab · S. Szegedi - N. Hommer · D. Schmidl ·

L. Schmetterer · G. Garhöfer ( $₫)$

Department of Clinical Pharmacology, Medical

University of Vienna, Vienna, Austria

e-mail: gerhard.garhoefer@meduniwien.ac.at

H. Stegmann - R. M. Werkmeister · L. Schmetterer Center for Medical Physics and Biomedical

Engineering, Medical University of Vienna, Vienna, Austria

S. Kaya

Department of Ophthalmology, Hietzing Hospital,

Vienna, Austria

distributed under the terms of the Creative Commons Attribution-NonCommercial 4.0 International License (http://creativecommons. org/licenses/by-nc/4.0/), which permits any non-commercial use, distribution, and reproduction in any medium, provided you give appropriate credit to the original author(s) and the source, provide a link to the Creative Commons license, and Indicate if changes were made.

The original article has been updated.

Open Access. This article is licensed under a Creative Commons Attribution-NonCommercial 4.0 International License, which permits any non-commercial use, sharing, adaptation, distribution and reproduction in any medium or format, as long as you give appropriate credit to the original author(s) and the source, provide a link to the Creative Commons licence, and

\footnotetext{
L. Schmetterer

Singapore Eye Research Institute, Singapore,

Singapore

L. Schmetterer

Nanyang Technological University, Singapore,

Singapore

L. Schmetterer

Ophthalmology and Visual Sciences Academic

Clinical Program, Duke-NUS Medical School,

Singapore, Singapore
} 
indicate if changes were made. The images or other third party material in this article are included in the article's Creative Commons licence, unless indicated otherwise in a credit line to the material. If material is not included in the article's Creative Commons licence and your intended use is not permitted by statutory regulation or exceeds the permitted use, you will need to obtain permission directly from the copyright holder.To view a copy of this licence, visit http://creativecommons.org/licenses/by/4. $0 /$. 